\title{
sciendo
}

CIVIL AND ENVIRONMENTAL ENGINEERING REPORTS

E-ISSN 2450-8594

CEER 2018; 28 (2): 150-163

DOI: $10.2478 /$ ceer-2018-0026

Original Research Article

\section{MONITORING AND NUMERICAL MODELING OF A ROAD IN LANDSLIDE TERRAIN}

\author{
Janusz P. KOGUT ${ }^{1}$, Elżbieta PILECKA ${ }^{1}$, Dariusz SZWARKOWSKI ${ }^{1}$ \\ Cracow University of Technology, Kraków, Poland
}

\begin{abstract}
Due to the significant role and noticeable development of transportation routes running from the north to the south of central Europe, several problems related to the construction and functioning of roads in the Carpathian foothills have been revealed. Recent climate change causes areas, where transport routes are particularly exposed to hazards, to succumb to technical exploitation and degradation. The elimination of the threats related to the activation of landslide phenomena becomes particularly expensive. Old roads, which were once designed for significantly lower axle loads and less heavy traffic conditions, are predominantly exposed. At the present, these roads are heavily exploited and have become overloaded. As a result, both the roadway and the subgrade undergo damage, which causes an increase in dynamic loads, and in potentially endangered areas, the activation of landslides. Landslides in the Carpathian flysch have a peculiar susceptibility to activation due to its geological structure. This paper addresses the problem of monitoring and analysing the effects of a landslide associated with the operation of a transportation route running through the slope of the Carpathian flysch. The studies include both field work and laboratory testing of basic geotechnical parameters. The parameters obtained during the geotechnical investigations, conducted for the purpose of building a numerical model, have been completed. The field work includes surveys made by a terrestrial laser scanner. The study also includes a number of $2 \mathrm{D}$ and 3D numerical models. These models, along with the substrate parameters, have been
\end{abstract}

${ }^{1}$ Corresponding author: Cracow University of Technology, Institute of Structural Mechanics, Warszawska st 24, 31-155 Kraków, Poland, e-mail: jkogut@pk.edu.pl, tel. +48126282579 
introduced into the FEA package and then calibrated. Subsequently, an analysis of the effects of landslide susceptibility and the behaviour of the road and terrain surface, due to the different variants of the loads, is shown along with the results of surveys.

Keywords: landslides, monitoring, stability, roads, numerical modeling

\section{INTRODUCTION}

Surface and subsurface soil mass movements pose a serious threat to economic activity and, often, to the health and life of people. The main, natural cause activating landslides are meteorological and hydrological phenomena, for example, intense or prolonged rainfalls in the summer and autumn periods and the rapid melting of snow and ice cover in early spring. In Poland, the region that is the most predisposed to the formation of landslides is the Carpathians. This region has valleys with high and steep slopes and its geological structure is composed of alternating layers of water-permeable sandstones and poorly permeable slate, clay and marl called flysch [1], and the presence of pits of lighter vulnerable susceptible to landslide processes, as well as tectonic construction (rock laying, cracks, faults) [2]. In the Carpathians, which cover about $6 \%$ of Poland, about $95 \%$ of all landslides registered in Poland were identified and are being recorded. In the most susceptible regions of the Carpathians, about $40 \%$ of the area is covered by landslides or other forms of soil mass movements. It is estimated that, in this region of Poland, for every square kilometre of area and for every $5 \mathrm{~km}$ of the road infrastructure network, there is one landslide, on average [3]. In the development of the road network in the Carpathians, one of the barriers is the high cost of development. Unfortunately, there are many old roads, which have not been renovated, that consequently have reduced design parameters. As a result of the changes related to the increase of the traffic and the loading carried by the axles of heavy vehicles, the risk related to the loss of stability of the routes and their sub-bases has increased. In addition, climate change contributes to the initiation and extension of Carpathian landslides.

This paper addresses the problem of monitoring and analysing the effects of a landslide associated with the operation of a transportation route running through the Carpathians. The parameters obtained during the geotechnical investigations, conducted for the purpose of building a numerical model, have been completed. The field work includes surveys made by a terrestrial laser scanner. The study also includes a spatial (3D) numerical model. An analysis of the effects of landslide susceptibility and the behaviour of the road and terrain surface, due to the different variants of the loads, is shown, along with the survey results. 


\section{LANDSLIDE AND ROAD STABILITY}

The geographical area in discussion is classified as the Beskid Wysoki mountain range. The average slope of its mountains ranges from 15 to $35 \%$, and the deep slots of the area with valleys and significant differences in height are conducive to the formation or the activation of landslides. The area of the landslide in question is located in the vicinity of Babiogórski National Park.

The research area is located in the active part of the landslide. Therefore, the section of the provincial road located along this section is at risk. The landslide card, developed in 2009, classifies the entire landslide as an old slumbering landslide that activates during periods of adequate hydro-meteorological conditions. The activation before 2009 damaged the local road and ran the risk of rupturing the road surface over a hundred meters. As a result, this section's embankment of the road was protected. According to the landslide card [4], it is sub-compact/complex, rock-like wasteland, the colluvium material is detritally blocky. The types of material are identified as Magura sandstones with Quaternary colluvium forms over them. Figure 1 shows the range of the landslide and comes from the landslide registration card. Figure 1 presents the landslide location.

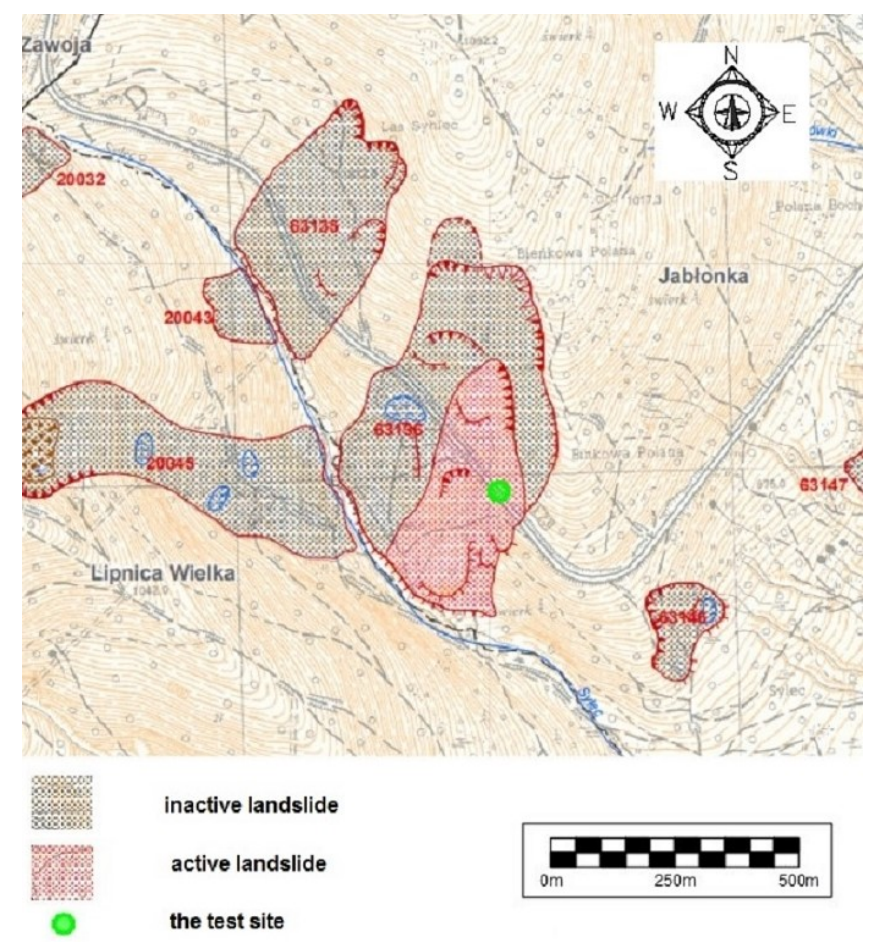

Fig. 1. Landslide and survey location [4] 
The landslide consists of a main slope of about $4 \mathrm{~m}$ high. In the upper part of the colluvium, there is a local road exposed to soil mass movements. On the asphalt surface, despite the renovation works, one may see the contour of a landslide niche. Above the local road, under the secondary escarpment, there is a zone of large wetlands, additionally supplied with a stream that flows periodically. The road surface is within the range of this zone, where the active part of the landslide is located. The landslide descends to the stream, where it has a height of approximately $5 \mathrm{~m}$. The colluvium area is regularly drained by a surface stream flowing through the culvert under the road, and the stream is at the foot of the slope.

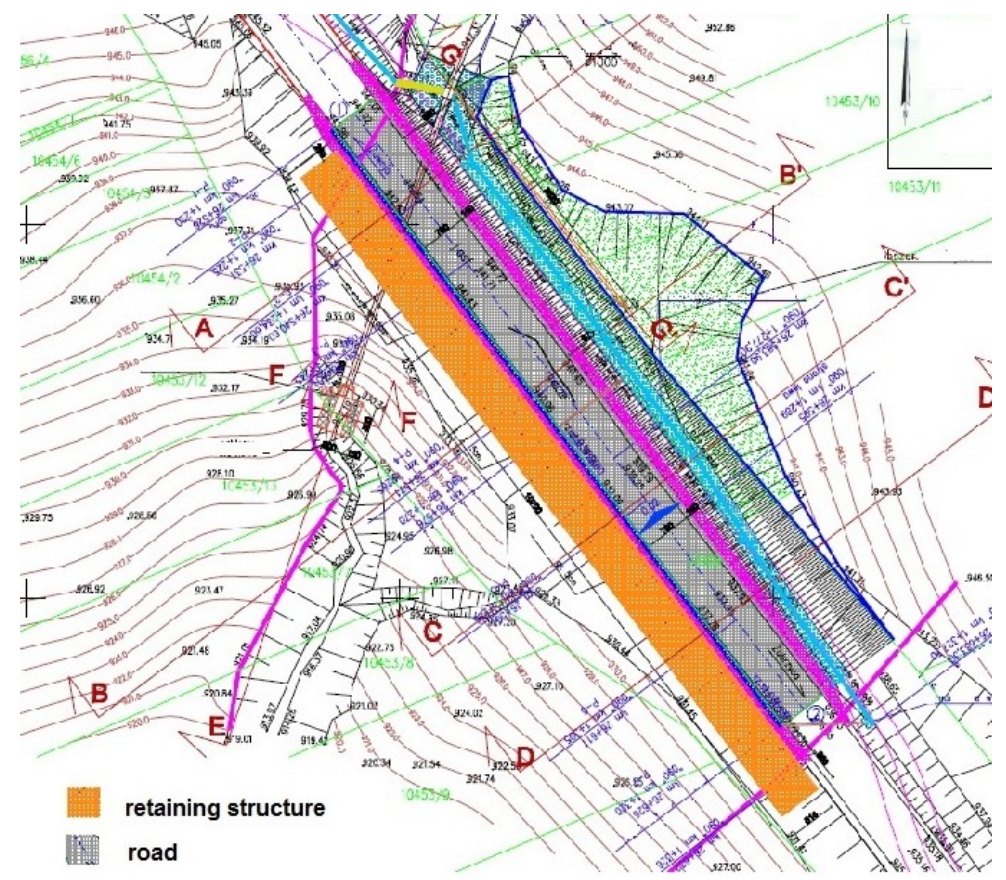

Fig. 2. Plan of development within the landslide and the local road

As part of the construction, a project to stabilize the landslide and the road was carried out on the $100.0 \mathrm{~m}$ long road. A reinforcement of the existing pavement structure, at a width of $7.00 \mathrm{~m}$ with both sides of the road paved with widths of $1.60 \mathrm{~m}$ and $1.85 \mathrm{~m}$, was performed. The rainwater was drained, in a controlled manner, to two wells and further by the road to the roadside ditches. There is no continuous aquifer in the quaternary area formations; however, the occurrence of water flow within the sandstone clayey deposits was identified. The water is 
coming from surface water infiltration. The intensity of the filtration is largely dependent on the amount of precipitation. The retaining structure is located along the road, below its edge. It was built in the form of a $20 \mathrm{~cm}$ thick reinforced concrete slab. The slab is fixed to the subsoil with ground anchors 40/16. For computations purposes, it was assumed that the probable slip surface is located at a depth of about $7.0 \mathrm{~m}$, while the anchoring was assumed to be in the layer of fine sandstone under the deepest slip surface, as specified by geological documentation. The length of there ground anchors were $15.0 \mathrm{~m}$ and $17.0 \mathrm{~m}$. The anchors were spaced $2.0 \mathrm{~m}$ apart in both directions and were finished with a $4 \mathrm{~m}$ long concrete end. The rods were fixed in a reinforced concrete slab with steel plates measuring $20 \times 20 \mathrm{~cm}$. The retaining structure is divided by a $5 \mathrm{~cm}$ wide dilatation into separate segments. Along the road, due to the need to widen the shoulder, the upper edge of each section was finished with a vertical wall thickness of $20 \mathrm{~cm}$. The wall height of $0.60-0.74$ was adjusted to the slope of the longitudinal road. In a reinforced concrete slab, horizontally mounted filters $\varnothing 10$ $\mathrm{cm}$ were placed at a distance of $2 \mathrm{~m}$ in both directions. Figure 2 presents the land development within the landslide and road.

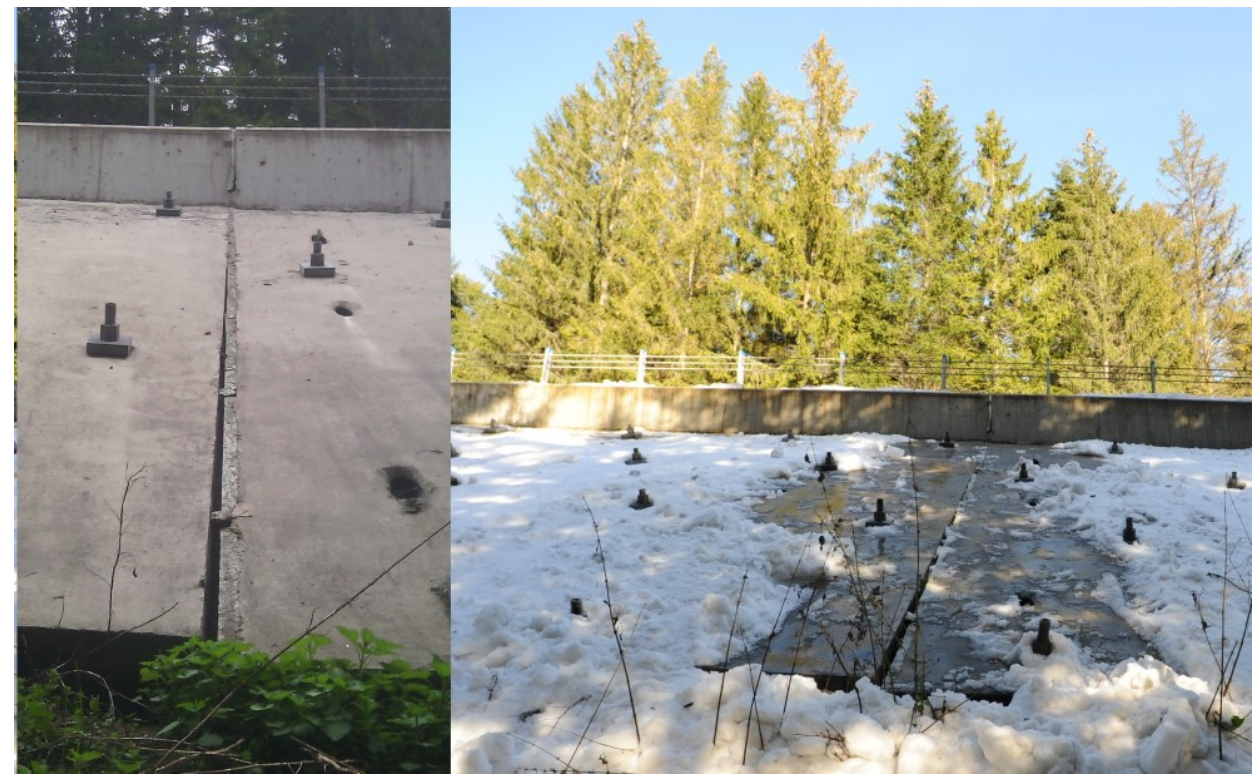

Fig. 3. Section of the failed slab of the anchored retaining structure

After a couple of years of intensive use of the road, considerable displacements were observed from the third, counting from the pass side, section of the retaining structure. The as-built inventory shows that the sections of the retaining structure have been visibly dislocated. The displacement is clearly visible in the upper part of the plate and measures $8 \mathrm{~cm}$ horizontally and $3 \mathrm{~cm}$ vertically. Figure 3 presents 
a picture of the failed slab of the anchored retaining structure from different perspectives, taken during the summer and winter measurement periods on site.

Table 1. Parameters obtained from the borehole during laboratory tests

\begin{tabular}{|c|c|c|c|c|c|c|c|c|c|}
\hline $\begin{array}{l}\text { Thickness } \\
{[\mathrm{m}]}\end{array}$ & $\begin{array}{l}\text { Depth } \\
\text { [m] }\end{array}$ & Type & $\begin{array}{c}\text { Natural } \\
\text { water } \\
\text { content } \\
{[\%]}\end{array}$ & $\begin{array}{l}\text { Density } \\
{\left[\mathrm{g} / \mathrm{cm}^{3}\right]}\end{array}$ & $\begin{array}{c}\text { Liquid } \\
\text { limit } \\
{[\%]}\end{array}$ & $\begin{array}{c}\text { Plastic } \\
\text { limit } \\
{[\%]}\end{array}$ & $\begin{array}{c}\mathrm{I}_{\mathrm{L}} \\
{[-]}\end{array}$ & $\begin{array}{l}\text { Effective } \\
\text { internal } \\
\text { friction } \\
\text { angle } \\
\text { [deg] }\end{array}$ & $\begin{array}{c}\text { Effective } \\
\text { cohesion } \\
{[\mathrm{kPa}]}\end{array}$ \\
\hline \multirow[t]{3}{*}{$0.2-2.0$} & 0.9 & $\begin{array}{l}\mathrm{Mm} \\
\mathrm{clGr}\end{array}$ & 10.1 & - & 23 & 17 & -1.0 & - & - \\
\hline & 1.2 & \multirow{11}{*}{$\mathrm{clGr}$} & 9.3 & 2.23 & - & - & - & 32 & 52 \\
\hline & 1.8 & & - & - & 29 & 17 & -0.3 & - & - \\
\hline \multirow[t]{2}{*}{$2.0-3.0$} & 2.1 & & 14.1 & - & 31 & 21 & -0.1 & - & - \\
\hline & 2.5 & & - & 2.18 & - & - & - & 11 & 35 \\
\hline \multirow[t]{2}{*}{$3.0-4.0$} & 3.3 & & 18.7 & 2.19 & - & - & - & 28 & 39 \\
\hline & 3.5 & & - & - & 29 & 19 & 0.1 & - & - \\
\hline \multirow[t]{5}{*}{$4.0-7.0$} & 4.6 & & 23.1 & - & 33 & 22 & - & - & - \\
\hline & 5.3 & & 13.2 & 2.17 & - & - & 0.2 & 13 & 35 \\
\hline & 5.5 & & - & - & 31 & 20 & 0.1 & - & - \\
\hline & 6.5 & & - & - & 38 & - & - & - & - \\
\hline & 6.6 & & 22.0 & 2.18 & - & - & - & 17 & 11 \\
\hline
\end{tabular}

The necessary field and laboratory steps were carried out to identify the cause for the excessive displacements of the reinforced concrete slab section. Among others, two boreholes were drilled together with the collection of the samples for laboratory tests. One of the boreholes was made using the mechanical and rotary method, on the water scrubber, a double core machine with a $\varnothing 116.95 \mathrm{~mm}$ drill. The drilling depth was $17 \mathrm{~m}$ in cross-section through the road corresponding to the excessively displaced section of the retaining structure.

The resulting cross-section is, according to the design, a road structure layer with a thickness of approximately $20 \mathrm{~cm}$, followed by a $20 \mathrm{~cm}$ foundation and an additional $35 \mathrm{~cm}$ substructure. At a depth of about $75 \mathrm{~cm}$ below the ground level, a geotextile that separates the main road structure from the modified substrate was found. The subsoil consists of successive layers of up to $2.00 \mathrm{~m}$ below the ground level, a strongly compacted layer of building embankment, and then sandstone clay, mainly with a stiff and firm consistency. At a depth of about 7-7.20 m below the ground level, a strongly cracked layer of sandstone appears at the drilling site, 
which is identified as a potential slip surface. Then, at a depth of $17 \mathrm{~m}$ below the ground level, there is a sandstone with a different degree of cracking. Nowhere in the cross-section is there free or suspended water.

During the fieldwork, a determination of the overall soil parameters from each geological layer was performed macroscopically with reference to the ISO procedure [5]. Later on, laboratory tests according to ISO code [6], were performed. The results are presented in the collective summary in Table 1 . The strength of the rock was also measured using a Schmidt hammer. These rocks are characterized by rather homogeneous strength parameters, namely within the range of $39.5 \div 45.5 \mathrm{MPa}$. The parameters determined during the tests, shown in Table 1, were applied to the numerical model built subsequently, as well as to further analyses.

\section{SURVEYING WORKS}

As part of the surveying work, a local situation and altitude map of the landslide was made using a Riegl Vz-400 terrestrial laser scanner. The scanner has high speed data acquisition with up to 500,000 measurements/sec, with a wide field of view $100^{\circ}$ over $360^{\circ}$. It has a range of measurements up to $800 \mathrm{~m}$, with $5 \mathrm{~mm}$ accuracy and precision of measurements about $3 \mathrm{~mm}$. The ordinates were determined using the method of direct survey in the field in the local coordinate system. Figure 4 shows a terrestrial laser scan of the site. It displays an image of the road and the landslide developed using the Riscanpro software package on a stretch of 75 meters. The image obtained, in the form of a cloud of points, may be compared with subsequent scans in order to monitor landslide movements.

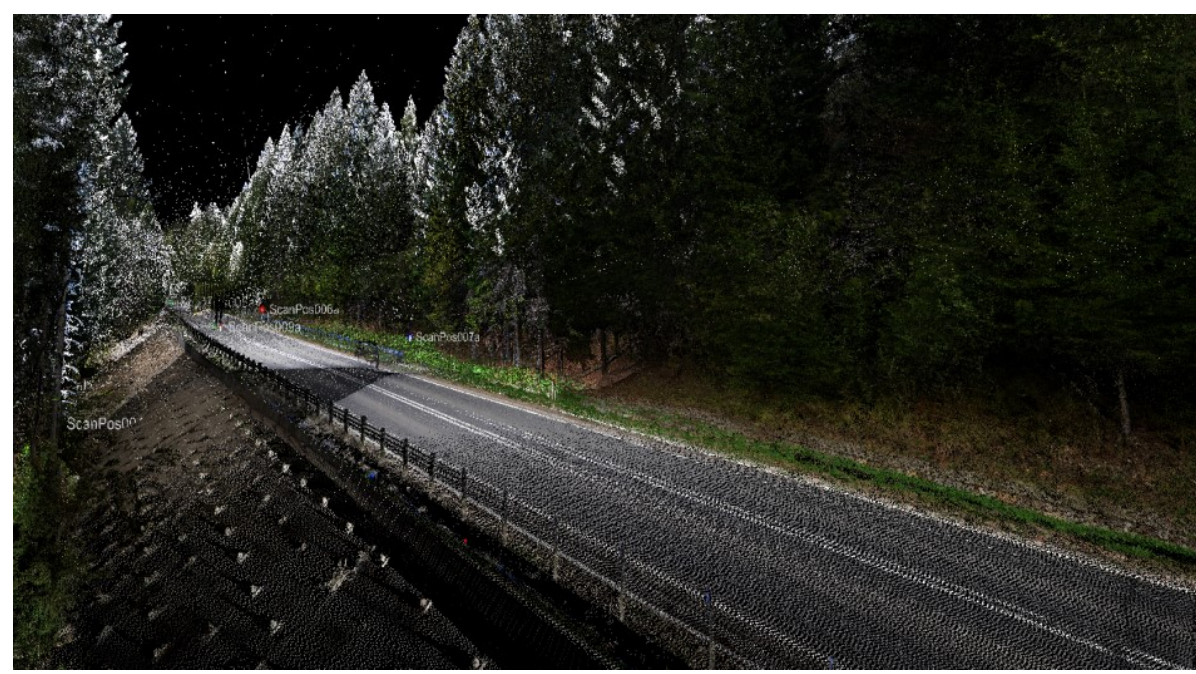

Fig. 4. Terrestrial laser scan within the analysed landslide 


\section{NUMERICAL MODEL}

A terrestrial laser scanner survey allowed us to apply the cloud map of the terrain to the numerical 3D model. Figure 5 presents the surface of the analysed slope with the road and the retaining structure extracted from the scan. The surface was then introduced into the FEA package [7]. It is commonly known that slope failure can occur if the internal shear stresses are greater than the shear strength of the slope soil. A slope stability analysis allowed us to calculate the safety of slope. There are various slope stability analysis methods, namely the Strength Reduction Method (SRM) and Stress Analysis Method (SAM).

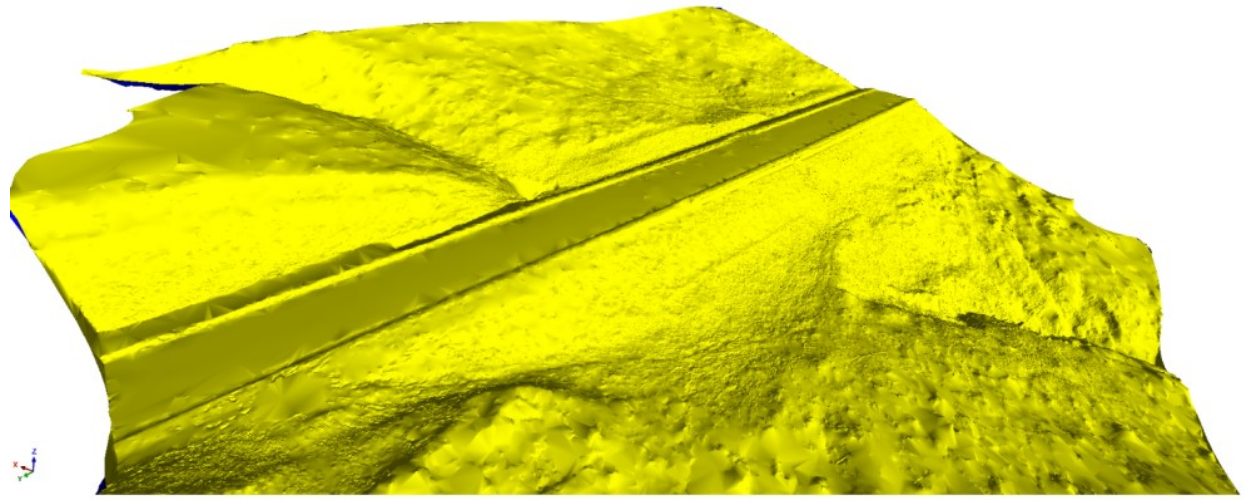

Fig. 5. Laser surface scan of the analysed landslide applied to the numerical model

SRM is non-linear method based on the limit equilibrium theory. The method analyses the minimum safety factor and failure behaviour using various shapes, loads, and boundary conditions. The SRM method may be used to simulate the failure process without any previous assumptions and may be applied to 3D problems. The SRM method gradually decreases the shear strength and internal friction angle until the calculation does not converge; the obtained point is considered to be the failure point of the slope. The maximum shear strength reduction ratio at that point is used to calculate the minimum safety factor of the slope. Stability by SRM is achieved by weakening the soil in an elastic-plastic discrete analysis until the slope fails. The Factor of Safety (Fos) is considered as the factor by which the soil strength is to be reduced to reach failure. Its main concept is the systematic reduction of the shear strength envelope of a material by a factor of safety and then performing the analysis of the slope until the deformation are unacceptably large or the solutions do not converge. SRM relies on arc length method, which computes the factor of safety that can accommodate a number of nodes and elements spread over the entire soil mass. The SRM is a time consuming non-linear analysis. However, due to the number of 
computations, quite accurate results are obtained. Moreover, the transition from the initial slope condition to slope failure is examined without having to assume the failure slope in advance [8]. The SAM method performs a stress analysis of the slope and calculates the Fos for each virtual slip surface, created from the assumptions of the limit equilibrium theory. The Factor of Safety is then calculated based on the stress analysis results. The minimum safety factor calculated for the various virtual slip surfaces becomes the Fos for the critical section computed.

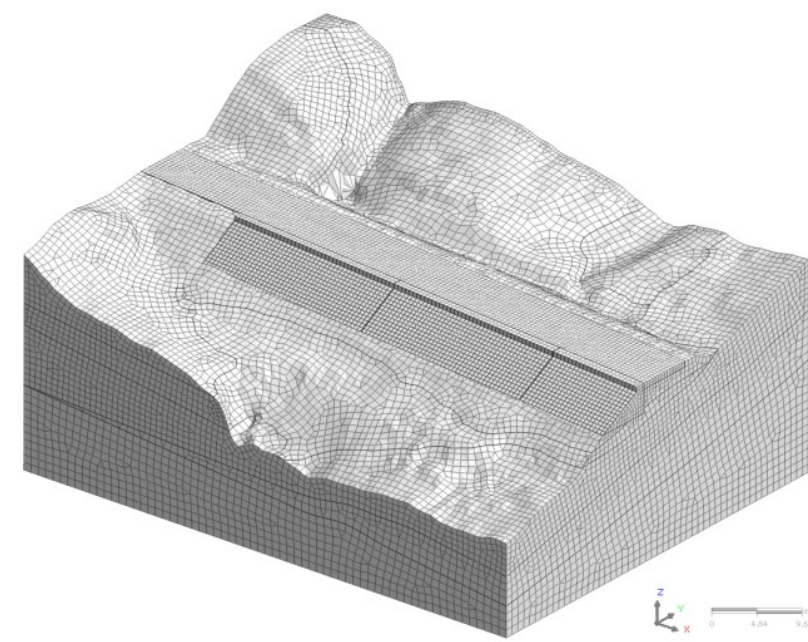

Fig. 6. Spatial FEM model mesh of the terrain with a retaining structure

The model utilized the data from the design documentation about the spatial variability of the subsoil and the soil effective parameters from the tests. The 3D model was built then and loaded with pointed forces corresponding to axles of several trucks, so that the rear axles were directly above the critical cross-section. Figure 6 presents the FEM model. The substrate was discretized by a finite element mesh. The ground anchors were added as pre-stressing cable elements, anchored to the concrete plates by one end and fixed into the substrate at the other. The number of nodes was equal to 120635 , while the number of elements was equal to 238703. The number of degrees of freedom was 366813, and the number of equations solved was equal to 337964 . Next, the calculations simulating the behaviour of the entire structure along with the ground were carried out by the SRM method in order to estimate the potential displacements and the slip surface. Two cases were considered. In the first case, the entire road was loaded with point loads corresponding to the truck's several axles, so that the rear axles were directly above the critical cross-section. The axle load was equal to $115 \mathrm{kN}$. Both 
lanes were loaded. The SRM analysis was performed and the Factor of Safety was computed.

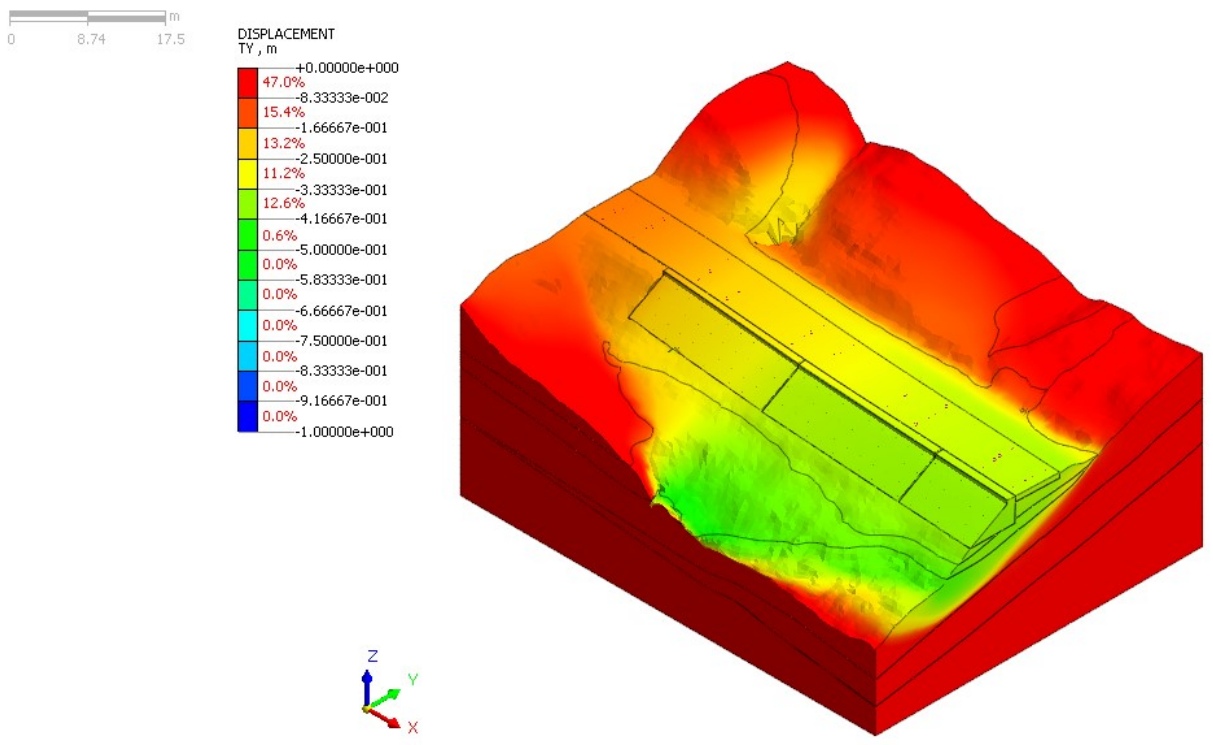

[DATA ] FOS2, Slope Stability(SRM), INCR=14 (FOS=1.4031), [UNIT ] $\mathrm{N}, \mathrm{m}$

Fig. 7. Horizontal displacements of a numerical model for the Fos $=1.403$ (case \#1)

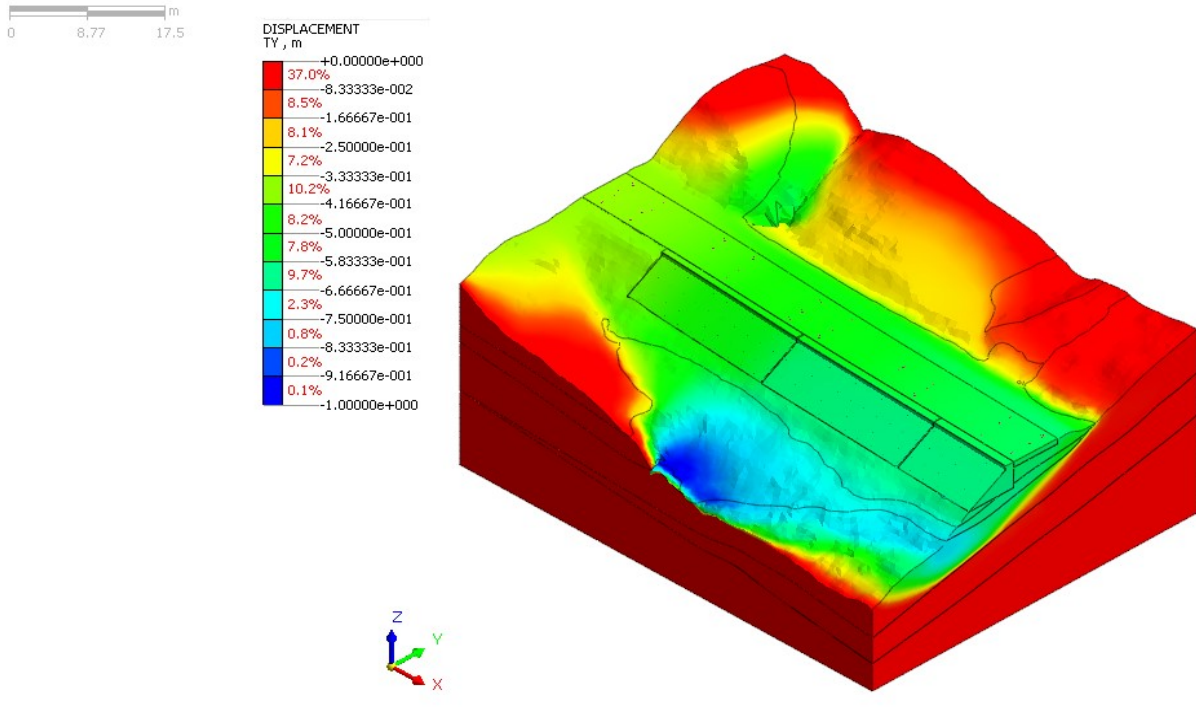

[DATA ] FOS, Slope Stability(SRM), INCR=15 (FOS=1.4563), [UNIT ] $\mathrm{N}, \mathrm{m}$

Fig. 8. Horizontal displacements of a numerical model for the Fos $=1.456$ (case \#2) 
Figure 7 presents an exemplary map of the horizontal displacements in the direction perpendicular to the road axis. It corresponds to the Factor of Safety Fos $=1.403$. The minimum Factor of Safety according to the instructions [9] and accepted by preexisting regulations [10] is equal to Fos $=1.5$. Figure 7 also illustrates the potential slip surface of the landslide.

In the second case, the part of the road, which is above the critical section, was loaded with point loads corresponding to the truck's axles, on both lanes. The SRM analysis was performed and the Factor of Safety was computed again.

Figure 8 shows a map of the horizontal displacements in the direction perpendicular to the road axis with a corresponding Factor of Safety Fos $=1.456$. Figure 8 also exhibits the potential slip surface, which is similar to the previous one.

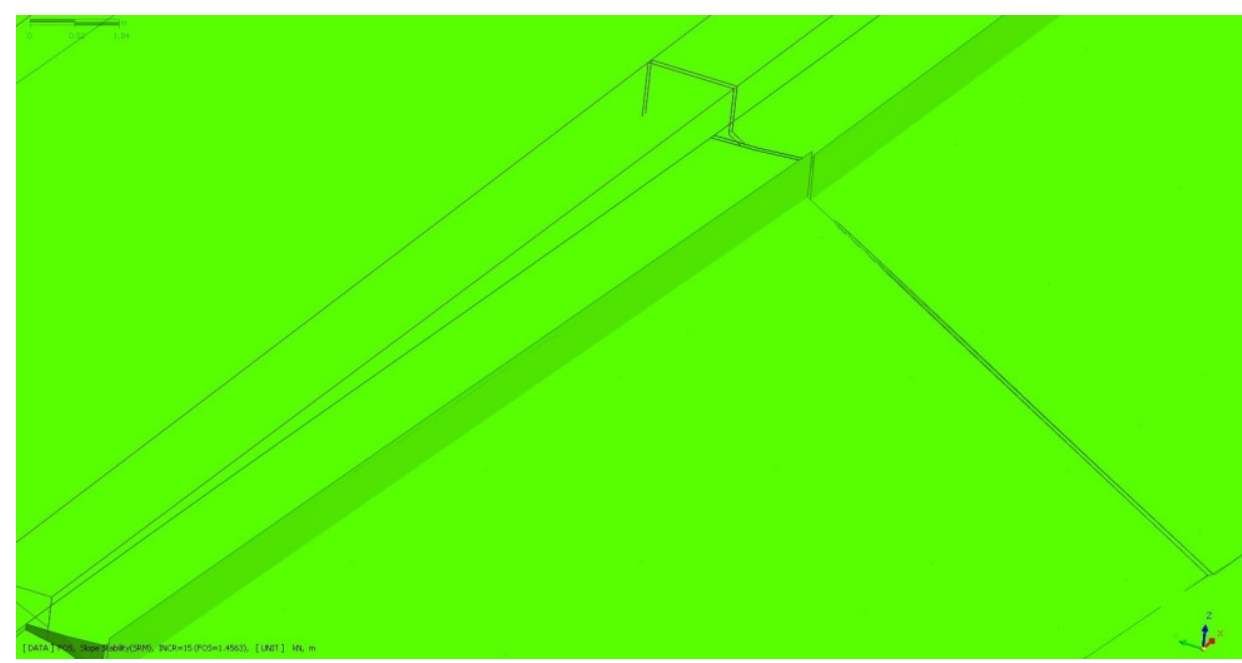

Fig. 9. Deformed part of the anchored retaining structure as modeled by FEM

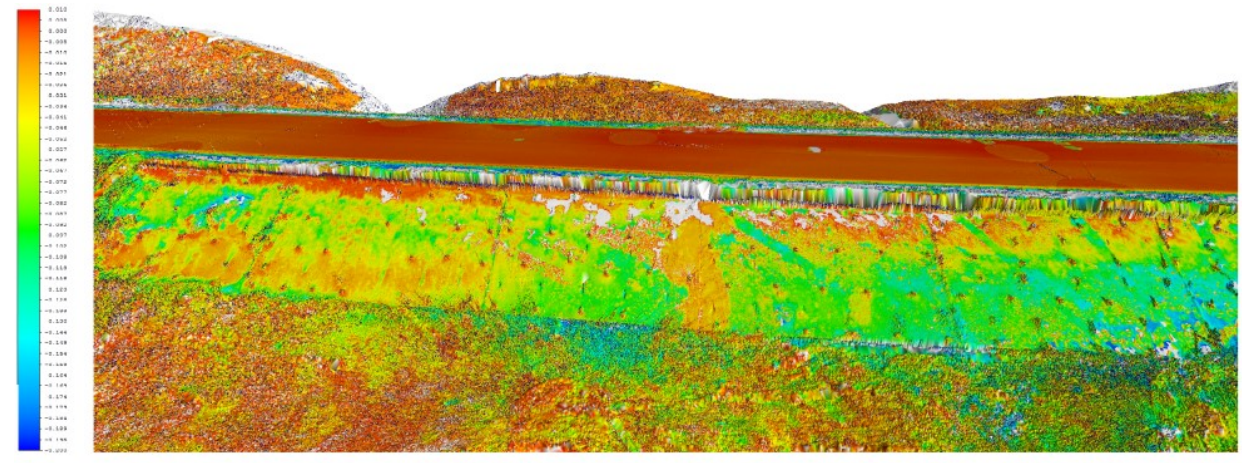

Fig. 10. Differential model of two consecutive laser scans of the road 
The deformed part of the anchored retaining structure with the critical section is shown in Figure 9. A comparison to Figure 3 gives the reader awareness of the adequacy of the discrete model acquired.

The slope and the retaining structure are the subject of regular measurements. The terrestrial laser scans are used to make a differential model and observe further landslide behaviour. An example of such a model is presented in Figure 10. Unfortunately, the concrete sections scans in this model are contaminated by snow and verdure, so the only reference is the road surface. It is visible from the picture that the surface seems to be stable with vertical displacements not exceeding $1 \mathrm{~cm}$. The retaining structure deformations do not threaten the stability of the road.

\section{FINAL REMARKS}

When considering the results of the investigation of the behaviour of a retaining structure built in order to protect a road running through a landslide, the following should be noted. The size of the landslide is much larger and terminates at the bottom of the slope. It has several active slip surfaces. Despite the stabilization of the road by the retaining structure, it is still active and should be monitored. The retaining structure has no support at the bottom edge. As a result, it is exposed to regular movements. It is recommended, based on the results of monitoring, to establish a protection for the most deformed sections. These may be additional elements, such as piles located at the foot of this structure, ending below the slip surface. It is possible to join the critical section together with the preceding section in a continuous manner that uses a flexible joint by affixing CFRP or ARFP tapes to the concrete using deformable adhesives and filling the dilatation with the deformable material. Especially after long-lasting heavy rain or spring thaw, complex construction work in landslide area is expected. Thus, the described structure should be properly inspected and documented each time.

\section{REFERENCES}

1. Harba P., Pilecki Z.: Assessment of time-spatial changes of shear wave velocities of flysch formation prone to mass movements by seismic interferometry with use of ambient noise. Landslide 14 (3), 1225-1233, DOI: 1007/s10346-016-0779-2. 2017.

2. Pilecki Z.: Basic principles for the identification of landslides using geophysical methods. E3S Web of Conferences 24 01001, DOI: 10.1051/e3sconf/20172401001, 2017. 
3. Bober, L., Thiel, L., Zabuski, L.: Zjawiska osuwiskowe w polskich Karpatach fliszowych. Geologiczno-inzynierskie własności wybranych osuwisk. Gdańsk: IBW PAN, 1997.

4. Rączkowski W.: Karta rejestracyjna osuwiska 12-11-052-001. The Polish Geological Institute - National Research Institute, 2009.

5. ISO 14688: 2017. Geotechnical investigation and testing -- Identification and classification of soil.

6. ISO 17892: 2014. Geotechnical investigation and testing - Laboratory testing of soil.

7. MIDAS GTS NX. Manual specifications, 2016.

8. Griffiths D.V., Lane P.A.: Slope Stability Analysis by Finite Elements, Geotechnique 49(3), 387-403, 1999.

9. Grabowski D., Marciniec P., Mrozek T., Neścieruk P., Rączkowski W., Wójcik A., Zimnal Z.: Instrukcja opracowania mapy osuwisk i terenów zagrożonych ruchami masowymi, The Polish Geological Institute - National Research Institute, 2008.

10. The Regulation of the Polish Ministry of Transportation of March 2, 1999 (Polish Journal of Laws No. 43, item 430).

\section{MONITORING I MODELOWANIE NUMERYCZNE DROGI KOŁOWEJ W TERENIE OSUWISKOWYM}

\section{Streszczenie}

Z uwagi na znaczącą rolę i rozwój szlaków komunikacyjnych przebiegających z północy na południe ujawniają się problemy związane $\mathrm{z}$ budową i eksploatacją dróg w podgórskich rejonach Karpat. Zmiany klimatyczne powodują, że obszary, w których przebiegają szlaki transportowe szczególnie narażone są na zagrożenia wynikające $\mathrm{z}$ ich technicznej eksploatacji i degradacji. Szczególnie kosztowna staje się likwidacja zagrożeń związanych z aktywacją zjawisk osuwiskowych. Mocno narażone pozostają stare drogi, które kiedyś projektowane były na znacznie mniejsze obciążenia osi pojazdów i inne warunki ruchu. W chwili obecnej drogi te są mocniej eksploatowane i bardziej przeciążone. Przez to zarówno jezdnia, jak i podbudowa ulega uszkodzeniom, co wywołuje zwiększenie obciążeń dynamicznych, zaś w rejonach potencjalnie zagrożonych, aktywację osuwisk. Osuwiska we fliszu karpackim charakteryzują się szczególną podatnością na aktywację ze względu na swoją budowę geologiczną. W pracy zajęto się problemem monitoringu i badania skutków wystąpienia osuwiska związanego z eksploatacją szlaku komunikacyjnego przebiegającego przez skarpę, której podłoże stanowi właśnie flisz karpacki. Dokonano zestawienia parametrów uzyskanych w trakcie badań geotechnicznych, prowadzonych na potrzeby budowy modelu numerycznego. 
Badania te obejmowały zarówno prace terenowe, jak i badania laboratoryjne podstawowych parametrów geotechnicznych. Prace terenowe uzupełniały pomiary geodezyjne wykonane skanerem laserowym. Zbudowano również szereg modeli numerycznych 2D i 3D. Modele te, wraz z przebadanymi parametrami podłoża zostały wprowadzone do pakietu MES, a następnie skalibrowane. W dalszej kolejności dokonano analizy skutków zagrożenia osuwiskowego i zachowania się drogi oraz podłoża przy różnych wariantach obciążeń oraz pokazano wyniki obserwacji geodezyjnych.

Słowa kluczowe: $\quad$ osuwiska, monitoring, stateczność, drogi, modelowanie

Editor received the manuscript: 21.06 .2018 